\title{
The Book in Communism: \\ Between Commerce, Culture, and Ideology. Some Remarks on Book Distribution and Propaganda during the Romanian Communist Regime
}

\author{
Raul PAVEL, PhD \\ Faculty of Communication and Public Relations \\ National School of Political and Administrative Sciences, Bucharest, Romania \\ E-mail: pavel.raul@student.comunicare.ro
}

\begin{abstract}
The paper discusses the system of book distribution in communist Romania and analyses the social role of the book in fostering a communist culture. By examining the intertwining relationships between the logistic and technical aspects of book production and the related cultural and economic discursive practices, we explore the processes by which books, as cultural artefacts, entered the realm of ideology. Furthermore, we look at how books and reading failed to produce disciplined readers and committed participants in the socialist system of values.
\end{abstract}

Keywords: Communism; Book; Publishing; Romania; Propaganda. 


\section{Introduction}

Reading and literacy, salient aspects of modern education (UNESCO, 2019), are inseparable of book publishing and print books (Pennington \& Waxler, 2018; Wolf, 2016; Clark \& Picton, 2019). Research of the book history during communism is of value because it allows us to map 'how ideas were transmitted by print and how exposure to the printed world affected [the] thought and behavior` (R. Darnton, $2009,176)$. Studying how the book circulated in communism - production, distribution and use - is part of a necessary effort in understanding the way modernity, politics and media interfaced with individual subjectivities, customs, and social practices. Book history is, then, a significant part of any historical, intellectual and political study of communism.

During the communist regime in Romania, books and reading had a contradictory fate. Both were presented in the political and cultural discourses as means of social mobility, similar to other socialist countries (Fitzpatrick, 1979). Along with education, reading in private had to continue the process of social integration and professionalization in an economy geared to rapid industrialization (Murgescu, 2010). As such, the book had a double function: on one hand, the book was a vehicle for the symbolic, historic and cultural meanings that represented the new social and political reality. On the other hand, it was a type of media that facilitated the political and economic meanings of the regime to be transmitted in the form of literary narratives and genres - most visible in the 'socialist-realist phase of literature, during the 1950's (Baghiu, 2019), but also in the 'socialist modernism ' of the 1960's through 1980's (Terian, 2019). Literature and language have been regarded throughout the communist era as powerful social instruments for change (Lovell, 2014), „weapons in the war of ideas” between socialism and capitalism (Hench, 2016), albeit dangerous in the absence of structures that monitor and censor. Censorship was instrumental in the creation of the literary landscape and in the implementation of the political agenda into the literary field (Corobca, 2014). Its main purpose was not the restriction of literary works into the public sphere, as much as the orientation of literary practices toward educational purposes, political propaganda (Macrea Toma, 2009) and national identity (Verdery, 1991). Book propaganda did not fulfil only a functional role of informational and linguistic control, but also suggested patterns of narrative, stylistic and aesthetic structures (Goldiș, 2011). It will try to bring forth a literature able to transfigure itself into a self-standing expression of socialist culture, to become part of a fixed repertoire of cultural practices. Ironically, this project was partially undermined by the material conditions of editorial production and book distribution, plagued by structural inefficiencies, a rigid hierarchy that let little room for administrative innovation and a philosophy of cultural production that emphasized productivity and quantity (Kornai, 1992; Verdery, 2003; Macrea Toma, 2009). Our goal is to paint a rep- 
resentative picture of these material conditions at the level of book distribution - bookstores and libraries.

\section{Context}

The history of the book is a well-developed area of research in most Western countries. Authors such as Lucien Febvre and Henri Jean-Martin (1976), Elizabeth Eisenstein (1980), Frederic Barbier (2017) or Robert Darnton (2018) have brought the field of book history to ever-greater recognition, becoming a staple research area for intellectual, literary and political history (Hall, 2007). Studies on the Soviet book industry are also relatively common. Titles such as Soviet Book Publishing Policy (Walker, 1978) and The Russian reading revolution (Lovell, 2014) are just two of the more well-known researches on the topic. Even in Romanian context, the history of the book is a relatively well researched sub-field of history (but without a distinct scholarly identity), at least until the end of the First World War, with research published as recently as a few years ago by Daniela Lupu (2014) and Bogdan Popa (2015). But the history of the book during the communist years in Romania is less researched, although there are still many former book professionals (typographers, booksellers, publishers) around and unexplored archives.

Some authors touched on the subject, as is the case with Cristian Vasile (2011), who delved into the cultural policies during the time of Gheorghiu-Dej and its editorial decision-making organisms. Macrea-Toma (2009) looked at the book production and distribution infrastructure, but only in a subordinate relation to the tensions and struggles between the literary field and state apparatuses. Liliana Corobca's (2014) research on the functioning of the Controlul Cărții (Book Control) section, part of the Direcția Literatură (Literature Directorate) inside the censorship institution Direcția Generală a Presei și Tipăriturilor (General Directorate of Print and Press) is exhaustive and rich of archival data, but it never mentions bookstores and libraries and it lacks an interpretation of its functioning beyond the letter of the archive.

As important and relevant as these and other studies are, all of them dealt with the book as a contingent aspect of the literary and cultural events of the times. Book publishing and the book industry at large have been often omitted or dealt with very briefly. The 'book' was present only when social, cultural and political forces summoned it. In many cases, the book is mentioned only when censorship and/or propaganda is alluded to.

This article is a study of the general material and ideological factors that affected book distribution in communist Romania, and consequently the difficulties of book-propaganda in reaching its stated goals of 'forming the socialist consciousness ' (Cazacu et al., 1964, 383) and the 'education and formation of the new man' (Ciont, Ciotloș, \& Balint, 1965, 10). Our main hypothesis is that the peculiarities 
and limitations characteristic of book distribution under Romanian socialism and the ideological constraints of the political regime have undermined the efficacy of propaganda by way of the book.

Some limitations in scope should be noted. This is not a comparative study of Romanian and Western book distribution. The similarities and differences with other Soviet countries are left largely unaddressed. The lack of significant sociological studies on reading and literacy - at the local or national level - in communist years is also a barrier to a deeper understanding of reading socio-demographics, consumption and behaviors. What studies this author has found, for example Ciont, Ciotloș \& Balint (1965), Bădina, Dumitriu \& Neamțu (1970), cover only certain rural areas, somewhat unsurprising since, as we will see, rural reading practices were of the utmost importance in the cultural policies of the times.

The first part of this study begins with an account of the relationship between propaganda and culture, in order to indicate some of the general assumptions and expectations to which book publishing was subjected. This is followed by a general presentation of the infrastructure of book distribution and the political context of its functioning. The paper will end with a conclusion section.

\subsection{Propaganda and culture}

We understand propaganda as a type of strategic communication, whose function is to persuade and disseminate messages and content through media channels. Its `orwellian` meaning involves the spread of false and misleading information, the manipulation and suppression of the subject's ability to properly evaluate the message (Marlin, 2007, 3671). Both meanings were active in the Romanian `real socialism ' between 1948 and 1989. Communist propaganda, although sometimes idealistic, hyperinflated or empirically incompatible with actual reality, was not always incompatible with what the state could promise to accomplish in a relatively legitimate manner, such as increased social mobility and an improvement of general material conditions. Books were important instruments in the propaganda tool box, functioning as a kind of soft power, a mean for the state to impose its pedagogical assumptions with regards to the cultural needs of the population and to modernize it according to its own ideological and political purposes (Macrea Toma, 2009, 162). Ultimately, the vision behind the socialist book-propaganda was the construction of a community of readers that had to be inseparable from the national and political project.

In the last decade of the regime, when economic growth was slowing down and the quality of life was stagnating (and then regressing) (Murgescu, 2010), the capacity of the regime to produce credible propaganda faltered. The 'transactional' practices that gave public homages and devotion to the communist leader - Nicolae Ceaușescu - in exchange for material resources (Macrea Toma, 2009), actively 
undermined objective decision-making at the administrative level. Television programs were reduced to a few hours a day, mostly covering the exploits of the 'dear leader ' (Matei, 2013), bookstores held on stock more copies of the titles published by Ceaușescu than those of contemporary and classic writers (Macrea Toma, 2009, 185), the number of published titles decreased each year (but their print-runs have gone up) (Macrea Toma, 2009, 61).

A structural-functionalist model of culture defined the sociological perspective of Romanian communism. Culture was `a well-integrated system of values, norms and symbols that served as society's master coordination system. Individuals internalized widely held societal values and their actions, guided by these values, then reproduces social organization at macro level` (Steensland \& Smith, 2012, 229-230). Every literary book was a miniature world that had to uphold the socialist values system, a fragment that had to represent the whole. Moreover, an ideological overlay stated that the Party is superior to individuals when it came to political consciousness and the objective interpretation of historical forces (Pollock, 2008). The belief in the scientific superiority of socialism and in the existence of clear and objective laws of history left little room for chance and contingency, public debates and criticism; even less so when it came to culture, which was among the first stones to be laid at the foundation of the new future. Books were the perfect means to accomplish the process of 'de-socialization', 're-socialization' and 'culturalization ' required by the new times. The population had to be de-socialized from the former cultural heritage and re-socialized under new social and political values (Shafir, 1983). What this signified was the necessity to transform the entire culture of the socialized. Culturalization meant that the ideological had to be inscribed in the common everyday (Boym, 1995, 105). Literature, among other things, had the function to normalize an ideological narrative about the nature of reality (Baghiu, 2019) and books had to transport these narratives along the four corners of the country.

A common myth in socialism, but also in Western countries (Matthews, 2004), was the productive function of the book. Released from capitalist exploitation and armed with the right books workers would work more conscientiously and more enthusiastic, resulting in increased productivity, lower costs with supervision and financial incentives (Walker, 1978, 8). The moral `superiority` of socialism produced an informal code of moral imperatives - discipline, sacrifice, vigilance, conservative family morals - as well as the 'right` literary tastes. Authenticity could be easily attacked as affected eccentricity, independence as individualism, a critical attitude as a lack of respect or worse, indiscipline. Rewarded behaviours (even in the absence of professional skills) were loyalty, fidelity, seriousness (Kornai, 1992, 57). Resistance to this new moral code was suspected to be contaminated by the ideas and attitudes of the old regime. Culture was the expression of how man can materially change its environment. The importance of heavy industry in commu- 
nist society was, thus, not only economic but also cultural. Cultural significance was produced by concrete action in the real world: 'the everyday act of the welder is an act of culture because it consciously participates in the achievement of a social goal’ (Neamțu, 1976, 190).

Required by the internal logic of the Marxist-Leninist formula of economic development and social progress, where productive forces and relations are the engines of history, a dominant material side is affixed to the meaning of culture. The 'conscious` action of transforming history, was always invoked by the propaganda in the hopes of rallying workers and boosting their productivity. Where the socialist project stagnated or did not return the expected results, such as the very slow growth of rural readers (Ciont et al., 1965), the response of the regime was to intensify propaganda through cultural events, cultural activism or increase the level of material investment (Macrea Toma, 2009), without really questioning the compatibility between context and theory. The productivist obsession of the regime regarding book production and other cultural goods (Kornai, 1992; Macrea Toma, 2009), tried to link the level of cultural production with the economic one. Culture had to represent in real time the stage of development of the other spheres of life, thus strengthening the legitimacy of the regime in the eyes of the citizens. In doing so, culture appears not as the result of an indefinite aggregation of cultural production (and endless struggles over what is culture), definite cultural production becomes the function of culture (defined around the communist ideology). Configured in this way, the cultural sphere turns into a subordinate field to politics and, due to the political control of economic resources, a resource allocation territory, as Janos Kornai (1992) would say. As in the Soviet publishing system, ideological content largely determined the value of a book (Walker, 1978).

Socialist values were (discursively) opposed to the primacy of possessive individualism, associated with capitalism and bourgeois culture. Book covers had to be sober and non-commercial (Buluță \& Simonescu, 1994, 91). The entertainment literature was disapproved of even if it was often published. (Nevertheless, this was not because the centralized editorial system was considering the public 'demand' and 'tastes', but as a tactic to subsidize editorial mistakes - unsold stocks (Macrea Toma, 2009). Moral failures were `repugnant remnants of bourgeois morality, such as careerism, intrigue, the appropriation of others' work, nepotism, plagiarism, etc.' (Erno, 1965, 333). Opposing capitalism, communists saw the encounter between culture and consumption as an expression of exploitation and symbolic impoverishment by the profit motive (Potîngă, 1972).

The public - aggregation of individual tastes -, was absent from the mechanisms that influenced the book trade. In the name of the public, editorial strategies and 'social orders' (titles deemed of social importance by various ministries, cultural institutions and political authorities) were conceived, although the public 
was never involved in defining what culture was, and it was not allowed to express its own reading tastes outside the official categories. Although literary fiction was the most read and sought after type of literature (Ciont et al., 1965), most published titles covered social and political subjects, and had the largest print-runs until 1975 (see Figure 1 and 2).

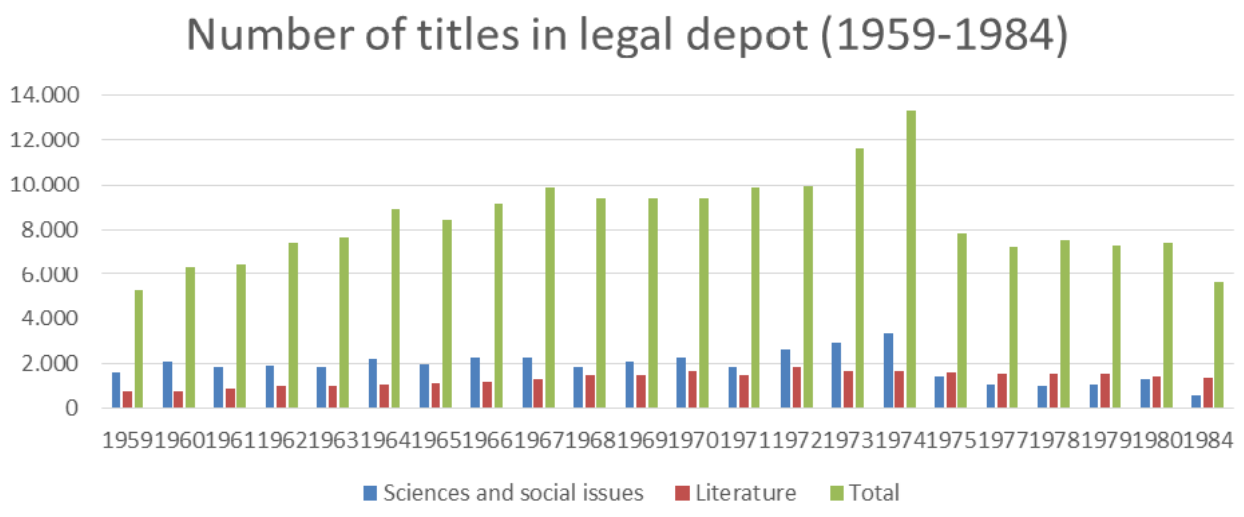

Figure 1. Compiled data from Romanian Statistical Yearbooks $(1965 ; 1970)(1975 ; 1980 ; 1985)$

\section{Sum of print-runs for titles entered legal depot (1959-1984)}

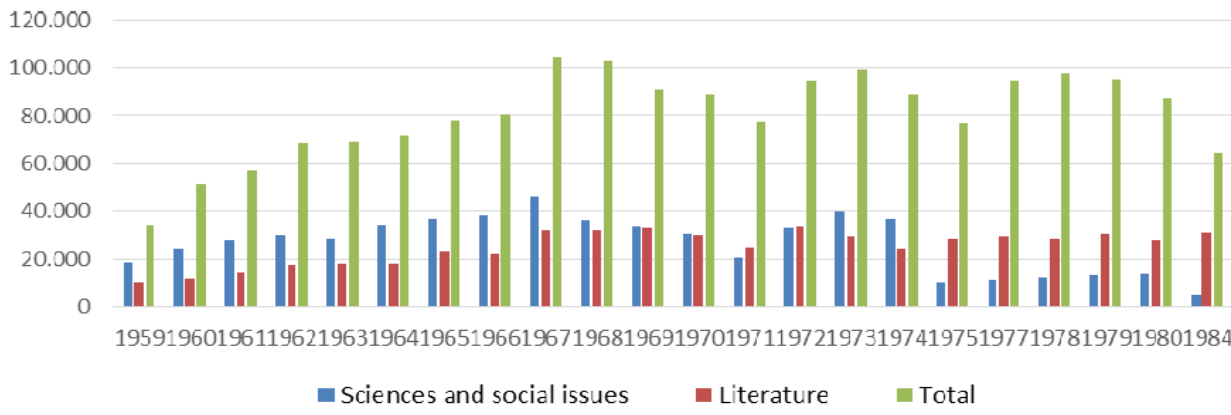

Figure 2. Compiled data from Romanian Statistical Yearbooks (1965; 1970) $(1975 ; 1980 ; 1985)$

The first years of communist regime in Romania have been under a publishing policy oriented toward the spreading of propaganda and the values imbued by the new socialist-realist literature (Negrici, 2010; Baghiu, 2019). However, the suspicion of genre literature and commercial fiction in general, was also a consequence of some very specific ideological beliefs. Gregory Walker gave a concise and clear 
description of the ethos that underpinned the understanding of publishing in Soviet culture in his Soviet Book Publishing Policy $(1978,7)$, a description that is valid as well for the Romanian context:

'It is common ground, among modem Soviet commentators on the subject, that a book, though a commodity, is a special kind of commodity; and secondly, that its status in a socialist society is qualitatively different from its status under capitalism. It is claimed that a Soviet author does not 'sell' a 'product', as an author would to a capitalist publisher, because the fee he receives is for the use of his work in the interests of all society, whereas the capitalist publishing-house has the two aims of maximum profit and of serving the interests of bourgeois society. (...) An excessively profit-orientated approach to publishing, at the expense of what are regarded as the interests of a socialist society, is often warned against; and the admonition has been made that to inflate a publishing-house's profits by such devices as increasing the issue of books in heavy demand, or simplifying the design of a work, is to satisfy 'commercial interests on an unhealthy basis'.'

'Undifferentiated satisfaction of 'raw' demand, as expressed in pre-publication orders and queues in bookshops, is not the primary aim of socialist publishing' (Walker, 1978, 9). The important thing was not consumer's `demand', but consumer's `needs`, a shorthand for 'authoritatively defined needs` (Walker, 1978, 9). That is why decisions regarding the 'thematic plan` (works which a publisher intends to publish in a determinate amount of time) had to take into account 'the right proportion of each type of book in the total output' (Walker, 1978, 9). Interlinked, the prospective interest of the command structures in book consumption rarely went beyond the sociological questionnaire that measured the efficacy of culturalization (Macrea Toma, 2009, 182), and has shown a strong inclination towards matters of economics and organization. Only very rarely, and mostly in the professional press, subjects as the disconnect between print-runs, published titles and public interests or the inefficient allocation of books to libraries were ever mentioned.

The discourse of a society founded upon knowledge and information, common message that accompanied the state's campaigns of reading and literacy in the 1960 's, never managed to go beyond propaganda. Even though political decisionmakers held the belief that the right books could positively influence the productivity of the workforce, the decisions taken by the state in this regard have been contradictory. Heavy industry was always favoured (receiving $85 \%$ of investment value), investments in human capital - education, culture, art - declining each decade (Murgescu, 2010, 338). Technical and specialist literature, the foundations of a society of knowledge and information, was 'permeated by a too long editorial and typographic process ` „Găsiți în cărțile tehnice ceea ce vă este necesar?”, 
1965, 3), when it was not downright irrelevant, unrelated to the needs of the public, without specialist endorsement, or redundant („Cartea științifică”, 1965, 4). Works of historical synthesis were absent, titles that required a long time to be elaborated were avoided, and the publishing plans were not forward-looking: 'the experience so far shows that instead of having initiative (...) publishers wait for the occasional offerings of authors or translators ... ` („Cartea de artă”, 1965, 4).

Finally, the relationship between publishers and distributors was mired by the complexity of the bureaucratic apparatus that could, unexpectedly and in a discretionary way, allocate promised resources to other industries.

'We design a book in a certain way, with a certain paper and a specific cover. Then, at the suppliers' pressures, we must make concessions after concessions: on the quality of the paper, the binding material, etc. Although the publisher prepares its plans and orders, a certain quality and quantity of paper, it finally receives something else. The fault of these disturbances in publishing production is borne by the specialized department of the Ministry of Chemistry. (...) Another thorny problem is that of printing. The Polygraphy Plant 'Scânteia House` has, say, two to three modern letter series, but it does not remove the second series from storage until it does not wear out the first. The issue of printing ink (...) should also be discussed („Cartea științifică”, 1965, 4).

\subsection{Bookstores and libraries}

Bookstores were not the main distribution channel, not only in a quantitative sense, but also in a cultural one: 'It is known that after the age of 25-30 years, if the interest in reading at the library (my emphasis) has not been formed, there are small hopes for reading to become a habit' (Revista Bibliotecilor, 1970, 77). The population segment to be served first consisted of 'readers whose education allowed them to have an intuitive literary taste, but not an explicit and rational judgment, whose working and living conditions make reading difficult or inaccessible, or whose lack of material resources forbids the frequent purchase of books` (Escarpit, 1980, 67). Bookstores were never the main distribution channel, as seen in Table 1.

Table 1. Book distribution in 1968 (Tranca \& Marinesco, 1968, 35)

\begin{tabular}{lccc}
\hline & Urban & Rural & Total \\
\hline Bookstores & 607 & 626 & 1233 \\
Bookstores in factories & 26 & - & 26 \\
Book areas in stores & - & 6628 & 6628 \\
"Book in the workplace" bookstands & 4915 & 10.636 & 15.651 \\
Book kiosks & 68 & - & 68 \\
Bookmobiles & - & 28 & 28 \\
\hline
\end{tabular}


After the public education system, the library was the place where reading skills were strengthened, and the state could continue its pedagogical involvement. Libraries, not books, created readers. Reading in the collective setting of the library expressed a social vision of the book. Although they are read individually, their value lies in how they can add to the common existence. Reading, unlike television and radio, was also considered by Ceausescu a better method of propaganda and social mobilization (Matei \& Marinkovic, 2018, 186). Proper reading was actively engaging moral and political faculties, and contributed to the collective good: 'to write, edit and buy books are as many acts of responsibility - not just an individual responsibility, but a collective, national one` (Geza, 1976, 1).

Investments in material infrastructure devoted to cultural activities were high, although deficient in many ways. Between 1938-1960, the number of cămine culturale (community centers in rural areas that also housed the local library) reached a high of 10.358 units. The total number of libraries was as high as 37.000 in 1950's, stabilizing just above 20.000 until 1989 .

But a large material infrastructure couldn't compensate for the deficiencies in administrative organization and its suboptimal results, which were visible to those involved (Vasile, 2011, 132). As Macrea Toma attest (2009, 160), after the reform of the publishing system in 1969 , overstocks increased from around $25 \%$ of total value to $40 \%$. Initiatives of reform existed but were undermined by internal struggles for political capital. During the time of Gheorghiu-Dej, various proposals like the centralization of distribution, increasing the number of access points and the number of 'book propagandists`, the reorganization of Centrul de Librării și Difuzarea Cărții (Bookstores and Book Distribution Center), increasing the editorial staff in publishing houses etc. got lost in a bureaucratic purgatory. The poor results of book propaganda-in the countryside was explained by Leonte Răutu, head of the Department of Agitprop (Propaganda and Agitation), by the existence of a bourgeois conspiracy in the leadership of the Publishing, Polygraphy, and Book Distribution General Directorate (Vasile, 2011, 134). Liability for unsold stocks or for inappropriately small print-runs moved between one institution and another. No one wanted to take responsibility for the failures of the book distribution system: the absence of book market studies, the lack of feedback mechanisms in publishing and sales (Moisil, 1970, 7), paper shortages, the allocation of resources on political grounds, a lack of hard constraints for unprofitable publishers - the last one a common state of fact in all other industries (Granick, 1975, 66). To recognize the true scale of such deficiencies would have been a political mistake, as they contradicted the specifics of the planned economy, but also the official view on the availability and openness of the population to socialist propaganda. Studies on reading and book consumption, though they existed, albeit in a restricted ideological paradigm, were not published or taken into account when cultural strategies 
were set (Schifirneț, 1991, 5), thus making the relationship between public, book distribution and publishers even more obscure and prone to haphazard.

One of the inefficient repetitive tactics deployed to 'solve` the slow pace of reading in rural areas was the organization of 'mass events' in libraries, criticized even by the Librarian's Guide, the librarian's professional magazine: mass book activities are 'prolix', they are organized around 'campaigns', not the interests of readers; they 'mobilize` readers whether they are interested or not. Notwithstanding that 'events are planned without considering the precise objective pursued by each of them and without categorically establishing the readers for whom they will be organized' (Călăuza Bibliotecarului, 1965, 712). The recommendations varied: the librarian's guidance should be done individually, not collectively; the number of mass events should not be taken to account in the evaluation of a librarian's work and, last but not least, 'a scientific selection of indicators in the establishment of print-runs, a more pronounced spirit of discernment from the decision sphere. The paradox is that the most searched works are edited in small print-runs` (Călăuza Bibliotecarului, 1965, 716). Librarians - rarely qualified and trained personnel (Revista Bibliotecilor, 1970, 104) - were under continuous pressure to carry on as many events as possible, even when they became forms empty of content.

Besides bookstores and libraries, book presentations and sales were held in factories and institutions around the country. These were necessary for publishers and bookstores to achieve their sales plan, but also because work schedules did not allow workers to visit bookstores and libraries. The solution was the creation of 'Book at Work' bookstands. It consisted of a volunteer book distributor, an employee of that institution or factory, who benefited from a $10 \%$ share of the value of the books he was selling to his colleagues (Vlas, 2007, 63). Payment could also be made through instalments, encouraging the purchase of many volumes. Books were cheap to buy since the most salient consideration in price setting was production costs and that book pricing 'should not hamper a book's circulation among the readers` (Walker, 1978, 11). State managed institutions, like Centrala Editorială (Publishing Central) established in 1970, decided what should be published, in what quantities and at what prices, with little or no input from bookstores, libraries or the publishers themselves. Certain specific, major products, such as the works of Stalin in the first years of communism and later those of comrade Ceaușescu, as well as 'social command titles, were always high on the publisher's list of priorities, allocating to them essential resources even in times of paper scarcity, hurting total titles output and print-runs for more profitable titles. Therefore, as we mentioned above, one would find more copies from the speeches of Ceaușescu than literature in bookstores.

Over-stocks were often sold to libraries or were forcedly distributed to bookstores and cooperatives. The writer I.M. Ştefan wrote in 1965: 'This year I was in 
the village of Fundata, 1300 meters above sea level, near Bran. As in other places, the store here sells books, sometimes between cheese and nails. The manager showed me lots of volumes, obviously unproductive there: a work on Kukrîniksi, a brochure on the growth of turkeys (occupation not practiced at Fundata) and a catalogue of the Romanian Academy Publishing House.' (Călăuza Bibliotecarului, 1965, 711-712). Most often than not, they were distributed to `Book at work` stands and sold 'per kilogram`. Books printed in limited print-runs were sold 'under the counter`, becoming valued objects of financial speculation.

'In large enterprises, we organized the distribution of 'packs' of books, which contained 10-12 different titles. It was a kind of 'wholesale`, almost 'per kilogram', I could say, because these packs contained works difficult to sell, but workers bought them in 5-6 instalments because 'it looked good` (my emphasis) to have a private library` (Vlas, 2007, 64).

Relaxed censorship between 1965 and 1971 brought no fundamental improvement in editorial, print or distribution processes (Macrea Toma, 2009). For example, one of the biggest problems of the publishing system was the very slow reaction to editorial success. Best sellers existed, but their success was not capitalized in a timely manner. The hierarchical and relational network of resource allocation (paper, typography) multiplied the already stretched response times. Print-runs were often over and underestimated for lack of market prospecting. Bookstores received books they did not ordered, those ordered came in altered quantities ${ }^{1}$. Authors were sometimes 'encouraged to purchase large quantities of their own titles to increase the quantity of copies allocated to a bookstore or city (Vlas, 2007, 92), so that publishers could reach their annual plans. In other instances, librarians 'doubled the price of sellable books to balance with them losses incurred through military or heroic texts` (Vlas, 2007, 92). Foreign books, for which there was a constant demand, rarely reached the bookstores, becoming an object of speculation, when it was not left unsold because of administrative disagreements regarding the selling price. The situation was of such a nature that in the late 1960s, in some bookstores, staff rotation schemes evolved to avoid the favouritism associated with personal relationships between booksellers and clients for highly sought titles (Macrea Toma, 2009, 185).

\section{Conclusion}

We have highlighted only a few of the more obvious dysfunctions of the Romanian book distribution system developed under communism. Its merits are not ignored - a large public had for the first time access to books - but it simultaneously

1 This has been confirmed to me by Rodica Grama, bookseller at CLB (Bookselling Center Bucharest) since 1964, in an interview that will be annexed to my upcoming $\mathrm{PhD}$ dissertation. 
had an inefficient public reach: the lack of studies on the reading public limited the impact of cultural policies; the productivist ethos behind publishing emphasized quantity instead of quality; the disconnect between print-runs, titles output and public interests had a negative effect upon reading practices. Ultimately, publishing and book distribution were most likely thought as enterprises to which industrial planning was well suited.

Books failed to produce 'the new man `due to three main reasons: 1) in cultural policies, reading was interpreted as a mostly productive and educational activity. Books were supposed to offer moral and political guidance, literary fiction or not, and to facilitate the acquisition of new skills and technical knowledge. Literacy was not the gate to a larger world, but a step toward the factory. 2) The material deficiencies of the book production and distribution system increased the effects of the first reason. First, by not taking stock of public tastes and interests. Book production was tightly interwoven with a moral set of norms that discriminated against 'proper' and 'improper` literature. Second, by prioritizing `social command publishing, the political elite left little room for publishers to respond in real time to public demand. Usually, what managed to get to the printer was disjointed from the interests of the reading public. 3) The hierarchical and relational nature of resource allocation limited publishing independence and compounded its structural inefficiencies.

The history of the book in communism has yet to become an independent area of research. The author of this study hopes that this will be just one of many articles that will pave the way for more research and critical inquiry of the subject.

\section{References}

1. Anuarul Statistic al Republicii Populare Române. (1965). București: Direcția Centrală de Statistică.

2. Anuarul Statistic al Republicii Socialiste Române. (1970). București: Direcția Centrală de Statistică.

3. Anuarul Statistic al Republicii Socialiste Române. (1975). București: Direcția Centrală de Statistică.

4. Anuarul Statistic al Republicii Socialiste Române. (1980). București: Direcția Centrală de Statistică.

5. Anuarul Statistic al Republicii Socialiste România. (1985). București: Direcția Centrală de Statistică.

6. Baghiu, Ștefan. (2019). The functions of socialist realism: Translation of genre fiction in communist Romania. Primerjalna Knjizevnost, 42(1), 119-132.

7. Barbier, F. (2017). Gutenberg's Europe. Cambridge: Polity.

8. Bădina, O., Dumitriu, D., \& Neamțu, O. (1970). Tineretul rural '68. București: Editura Academiei. 
9. Boym, S. (1995). Common places. Mythologies of everyday life in Russia. Cambridge: Harvard University Press.

10. Buluță, G., \& Simonescu, D. (1994). Scurtă istorie a cărții românești. București: Editura Demiurg.

11. Cartea de artă. (1965). Scânteia (6826) p. 4, București,

12. Cartea științifică. (1965). Scânteia (6807), p. 4, București.

13. Cazacu, H., Cernea, M., Chepeș, Gh., \& Vlad, C. (1964). Profilul spiritual al clasei muncitoare în socialism. București: Editura Academiei RPR.

14. Călăuza Bibliotecarului. (1965). (1-12), București.

15. Ciont, E., Ciotloș, I., \& Balint, Gh. (1965). Lectura la sate în regiunea București. București: Comitetul de stat pentru cultură şi artă.

16. Clark, C., \& Picton, I. (2019). Children, young people and digital reading [Research]. Preluat în din National Literacy Trust website: https://literacytrust.org.uk/documents/2379/ Reading_digitally_-_April_2019.pdf

17. Corobca, L. (2014). Controlul Cărții. București: Cartea Românească.

18. Darnton, R. (2009). The Case for Books: Past, Present, and Future. Preluat în din https:// books.google.ro/books?id=KplFSD-VP_QC

19. Darnton, Robert. (2018). A literary tour de France. Oxford: Oxford University Press.

20. Davis, P. (2013). Reading and the Reader. Oxford: Oxford University Press.

21. Eisenstein, E. (1980). The printing press as an agent of change. Cambridge: Cambridge University Press.

22. Elfenbein, A. (2018). The gist of reading. Stanford University Press.

23. Erno, G. (1965). Intelectualitatea în viața socială. București: Editura Științifică.

24. Escarpit, R. (1980). De la sociologia literaturii la teoria comunicării. București: Editura Științifică și Enciclopedică.

25. Febvre, L., \& Martin, H. J. (1976). The Coming of the Book: The Impact of Printing 14501800. Preluat în din https://books.google.ro/books?id=9opxcMjv4TUC

26. Fitzpatrick, S. (Ed.). (1979). Education and Soviet society. În Education and Social Mobility in the Soviet Union 1921-1934 (pp. 3-17). https://doi.org/10.1017/CBO9780511523595.001

27. Găsiți în cărțile tehnice ceea ce vă este necesar? (1965). Scânteia(6604), p. 3, București.

28. Geza, D. (1976). Cărți și editori. Contemporanul, p. 1, București.

29. Goldiș, A. (2011). Critica în tranșee. De la realismul socialist la autonomia esteticului. Bucharest: Cartea Românească.

30. Granick, D. (1975). Enterprise guidance in Eastern Europe. Princeton: Princeton University Press.

31. Hall, D. A. (2007). What was the history of the book? A response. Modern Intellectual History, 4(3), 537-544. https://doi.org/10.1017/S1479244307001400

32. Hench, J. B. (2016). Books as weapons. Propaganda, Publishing, and the battle for Global Markets in the Era of World War II. New York: Cornell University Press.

33. Kornai, J. (1992). The Socialist System. Oxford University Press.

34. Lovell, S. (2014). The Russian Reading Revolution. Palgrave Macmillan UK. 
35. Lupu, D. (2014). Tiparul și cartea din Țara Românească în epoca domniei fanariote. București: Muzeul Mincipiului București.

36. Macrea Toma, I. (2009). Privilighenția. Cluj-Napoca: Casa Cărți de Știință.

37. Marlin, R. (2007). Propaganda. În G. Ritzer (Ed.), The Blackwell Encyclopedia of Sociology (pp. 3671-3675). Blackwell.

38. Matei, A. (2013). O tribună captivantă. București: Curtea Veche.

39. Matthews, K. L. (2004). The re(a)d menace: Cold War fiction and the politics of reading. Wisconsin-Madison, Wisconsin.

40. Moisil, G. C. (1970). De ce se vinde și de ce nu se vinde cartea de artă. Contemporanul, p. 7.

41. Murgescu, B. (2010). România și Europa. Acumularea decalajelor economice (1500-2010). Iași: Polirom.

42. Neamțu, O. (1976). Cultura ca acțiune socială. București: Editura Academiei RSR.

43. Negrici, E. (2010). Literatura română sub comunism: 1948-1964. București: Cartea Românească.

44. Pennington, M. C., \& Waxler, R. P. (2018). Why reading books still matter. The power of literature in digital times. New York: Routledge.

45. Pollock, E. (2008). Stalin and the Soviet Science Wars. Princeton: Princeton University Press.

46. Popa, B. (2015). Comerțul cu carte în România: Proiect național și proiect economic (a doua jumătate a secolului al XIX-lea - începutul secolului al XX-lea). Cluj-Napoca: Academia Română - Centrul de studii transilvane.

47. Popa, C. (2018). Intelectualii lui Ceaușescu și Academia de Științe Sociale și Politice (19701989). București: Litera.

48. Potîngă, C. (1972). Socialismul și cultura de masă. Iași: Editura Junimea.

49. Revista Bibliotecilor. (1970). (1-12), București.

50. Schifirneț, C. (1991). Lectura și biblioteca publică. București: Biblioteca Municipală Mihail Sadoveanu.

51. Shafir, M. (1983). Political culture, intellectual dissent and intellectual consent: The case of Romania. Orbis, 393-420.

52. Steensland, B., \& Smith, C. M. (2012). Culture, State and Policy. În E. Amenta, K. Nash, \& A. Scott (Ed.), The Wiley-Blackwell Companion to Political Sociology (I, pp. 229-239). Blackwell Publishing.

53. Terian, A. (2019). Socialist Modernism as Compromise: A Study of the Romanian Literary System. Primerjalna književnost, 1(42), 133-147.

54. Tranca, D., \& Marinesco, I. (1968). Aperçu sur le livre en Roumanie. București: Meridiane.

55. UNESCO. (2019). Sustainable development goals. Preluat în 11 octombrie 2019, din Www.un.org website: https://www.un.org/sustainabledevelopment/education/

56. Vasile, C. (2011). Politicile culturale comuniste în timpul regimului Gheorghiu-Dej. București: Humanitas.

57. Verdery, K. (1991). National Ideology under Socialism. University of California Press. 
58. Verdery, K. (2003). Socialismul: Ce a fost și ce urmează. Iași: Institutul European.

59. Vlas, I. (2007). Amintirile unui librar. Cluj-Napoca: Editura Accent.

60. Walker, G. (1978). Soviet book publishing policy. Cambridge: Cambridge University Press.

61. Wolf, M. (2016). Tales of literacy for the 21st century. Oxford: Oxford University Press. 